\title{
PENINGKATAN PERAN PEMERINTAH DAERAH DALAM RANGKA PENGEMBANGAN EKONOMI KREATIF DI PROVINSI JAWA BARAT
}

\author{
ENHANCING THE ROLE OF LOCAL GOVERNMENT \\ CREATIVE ECONOMY DEVELOPMENT IN ORDER \\ IN WEST JAVA PROVINCE
}

\author{
Rosmawaty Sidauruk \\ Badan Penelitian dan Pengembangan Kementerian Dalam Negeri \\ Jalan Kramat Raya No.132 Jakarta Pusat \\ e-mail: waty.sidauruk@yahoo.com
}

Diterima: 5 Juli 2013; direvisi: 13 Juli 2013; disetujui: 18 September 2013

\begin{abstract}
Abstrak
Penelitian ini dilakukan untuk mengetahui apakah pemerintah daerah provinsi Jawa Barat telah melaksanakan pengembangan ekonomi kreatif, dengan melihat bentuk kebijakan dan dukungan anggaran dalam APBD dan permasalahannya. Metode yang digunakan survey formatif. Informannya aparat Bappeda,Biro Perekonomian, Dinas perindustrian, pelaku usaha ekonomi kreatif. Hasil penelitian menunjukkan, Pemerintah Provinsi Jawa Barat sudah membuat peraturan daerah dan cetak biru ekonomi kreatif Permasalahan antara lain: masih sulit memisahkan antara sub sektor industri kreatif dengan sektor lainnya sehingga penganggarannya belum khusus bernama kegiatan ekonomi kreatif, belum optimalnya kemudahan perijinan, investasi dan perlindungan HAKI, masalah permodalan, dan daya dukung riset terhadap ekonomi kreatif masih kurang. Disarankan perlu lebih berkomitmen siap memfasilitasi pemasaran hasil, mempermudah akses pelaku usaha terhadap perbankan, perlindungan HAKI, peningkatan kerjasama antara provinsi dan kabupaten/kota untuk keberlanjutan bahan baku yang diperlukan.
\end{abstract}

Kata kunci: Pemerintah daerah, pengembangan, bakat individu,ekonomi kreatif .

\begin{abstract}
This study was conducted to determine whether the West Java provincial government has undertaken the development of the creative economy, with a look at the form of policy and budget support in the budget and problems. Formative survey methods used. Bappeda informant apparatus, Bureau of Economic, Department of Industry, creative economy businesses. The results showed, West Java Provincial Government already made a blueprint of local regulations and creative economy issues, among others: still difficult to separate the creative industry sub-sector with other sectors so that budgeting is not specifically named creative economic activity, not optimal ease of licensing, investment and protection of intellectual property, the problem of capital, and the carrying capacity study of the creative economy is still lacking. Suggested need to be committed is ready to facilitate marketing, businesses easier access to banking, intellectual property protection, increase cooperation between the provincial and district / city for the sustainability of the raw materials required.

Keywords: Local government, development, individual talents, the creative economy
\end{abstract}

\section{PENDAHULUAN}

Munculnya ekonomi kreatif dalam ekonomi dunia, sebenarnya diawali dari adanya pergeseran orientasi dunia barat yakni dari era pertanian ke era industrialisasi yang kemudian disusul era informasi yang disertai dengan banyaknya penemuan baru di bidang teknologi informasi dan komunikasi (infokom) serta globalisasi ekonomi.

Penemuan baru di bidang teknologi infokom misalnya seperti internet, email, SMS, Global System for Mobile Communication (GSM) telah menciptakan interkoneksi antar manusia, yang membuat manusia menjadi semakin produktif dan gaya hidup dan perilaku masyarakat menjadi lebih kritis dan lebih peka atas rasa, serta pasar pun menjadi semakin luas dan semakin global dan muncullah "kompetisi yang semakin keras".

Negara-negara maju makin menyadari bahwa saatnya mereka tidak bisa mengandalkan supremasi di bidang industri lagi, tetapi mereka harus lebih mengandalkan semberdaya manusia (SDM) yang kreatif, sehingga pada tahun 1990-an dimulailah era ekonomi baru, yang mengintensifkan informasi dengan kreatifitas yang populer disebut ekonomi kreatif yang digerakkan oleh sektor industri yang 


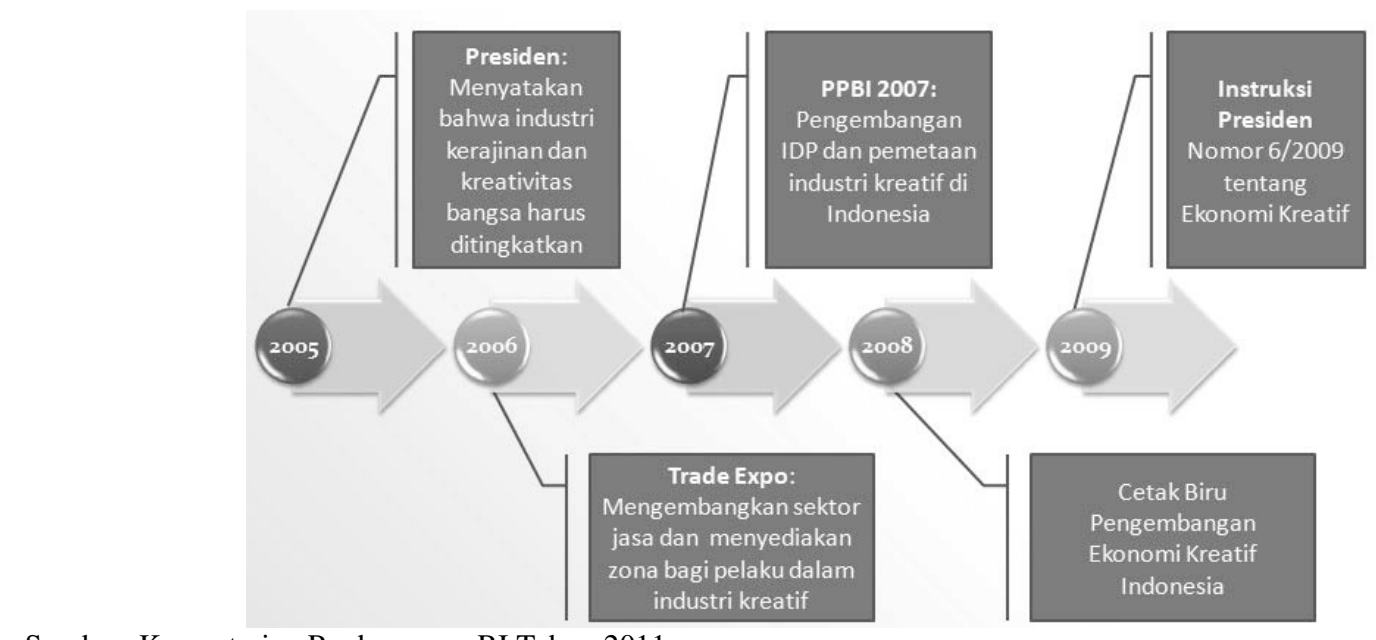

Sumber: Kementerian Perdagangan RI Tahun 2011

Gambar 1: Batu Capaian (Milestones) Ekonomi Kreatif di Indonesia.

disebut industri kreatif (Kementerian Perdagangan, 2008).

Berdasarkan penjelasan singkat di atas dapat diketahui, bahwa ekonomi kreatif sebenarnya adalah wujud dan usaha mencari pembangunan yang berkelanjutan melalui kreativitas, yang mana makna pembangunan berkelanjutan itu adalah suatu iklim perekonomian yang berdaya saing dan memiliki cadangan sumberdaya yang terbarukan (Kementerian Perdagangan, 2008). Pesan besar yang ditawarkan ekonomi kreatif adalah pemanfaatan cadangan sumberdaya yang bukan hanya terbarukan, tetapi juga tak terbatas yaitu ide, talenta, dan kreativitas.

Berdasarkan data Kementerian Perdagangan (2008), peran industri kreatif dalam ekonomi Indonesia cukup signifikan, dengan kontribusi sebesar 6,3\% atau setara dengan Rp. 104,6 trilyun (nilai konstan) dan Rp.152,5 trilyun (nilai nominal), hal ini dilihat dari kontribusi PDB rata-rata pada tahun 2002-2006. Dilihat dari sisi ekspor, berdasarkan estimasi klasifikasi subsektor, maka kontribusi ekonomi kreatif terhadap total ekspor rata-rata sebesar 10,6 \% untuk tahun 2002-2006.

Berdasarkan data empiris di atas, maka disimpulkan bahwa ekonomi kreatif di Indonesia mempunyai peluang yang signifikan terhadap perekonomian nasional, penciptaan bisnis, dan dukungan pada pencitraan dan identitas bangsa, meskipun disadari ada tantangan yang dihadapi.

Pada dasarnya ekonomi kreatif telah tumbuh dan berkembang sejak negara Indonesia ada (Kementerian Perdagangan RI, 2011), akan tetapi baru mendapat perhatian yang khusus sejak tahun 2005, pada tahun inilah pemerintah telah meletakkan batu-batu capaian (milestones) dan setiap capaian tersebut menjadi titik yang menginspirasi pengembangan ekonomi kreatif. Secara runtut batu capaian (milestones) ekonomi kreatif di Indonesia dapat dikemukakan pada gambar 1.
Secara seremonial Cetak Biru Pengembangan Ekonomi Kreatif di Indonesia, telah diserahkan oleh Menteri Perdagangan RI. kepada Presiden RI pada tanggal 4 Juni 2008, terdiri dari 2 (dua) bagian utama yaitu pertama, Rencana Pengembangan Ekonomi Kreatif 2009-2015, kedua, Rencana Pengembangan 14 (empatbelas) sektor Industri Kreatif 2009-2015. Mengacu pada Cetak Biru dimaksud, Kementerian Perdagangan menggodok Instruksi Presiden yang bertujuan untuk mengajak seluruh instansi pemerintah untuk "Mendukung Kebijakan Pengembangan Ekonomi Kreatif Tahun 2009-2015" yaitu: "pengembangan kegiatan ekonomi berdasarkan pada kreativitas, keterampilan, dan bakat individu untuk menciptakan daya kreasi dan daya cipta individu yang bernilai ekonomis dan berpengaruh pada kesejahteraan masyarakat Indonesia, dengan sasaran, arah, dan strategi yang telah ditetapkan dalam cetak biru".

Dengan demikian terbitlah Instruksi Presiden Nomor 6 Tahun 2009 tentang Pengembangan Ekonomi Kreatif pada tanggal 5 Agustus 2009 dan cetak biru tersebut merupakan bagian yang tak terpisahkan dari Instruksi Persiden dimaksud. Instruksi Presiden tersebut sifatnya imperatif yang menginstruksikan kepada 27 Kementerian dan Lembaga (K/L) serta Gubernur, Bupati/ Walikota seluruh Indonesia untuk mendukung kebijakan Pengembangan Ekonomi Kreatif Tahun 2009-2015.

Inpres No 6 Tahun 2009 tersebut secara sistemik menetapkan 6(enam) sasaran, 21(duapuluh satu) arah, dan 83 (delapanpuluh tiga) Strategi Pengembangan Ekonomi Kreatif Tahun 2009-2015. Yang menjadi pertanyaan adalah: a) Bagaimanakah wujud nyata peran Pemerintah Daerah Provinsi, Kabupaten/Kota dalam menindaklanjuti Inpres tersebut?, b) apakah dalam hal ini Pemerintah Daerah harus menunggu ditetapkannya Norma, Standar, Prosedur, dan Kriteria (NSPK) oleh 
Pemerintah baru kemudian Pemda melaksanakan instruksi dimaksud? Kedua pertanyaan tersebut adalah masalah krusial bagi Pemerintah Daerah dalam menindaklanjuti Inpres No 6 Tahun 2009 dan sementara itu Kemendagri baik sebagai K/L yang menerima dan melaksanakan Inpres tersebut yang harus menyusun dan melaksanakan Rencana Aksi Pengembangan Ekonomi Kreatif, maupun sebagai pembina Pemda yang merekomendasikan atas pelaksanaan Inpres dimaksud.

Dalam kaitan itulah Kajian ini dilaksanakan dengan judul Peningkatan Peran Pemerintah Daerah dalam rangka Pengembangan Ekonomi Kreatif,dengan studi kasus di Provinsi Jawa Barat . Kedua pertanyaan ini kemudian dielaborasi menjadi rumusan permasalahan yaitu " Apakah Pemerintah Derah Provinsi Jawa Barat telah menyusun dan melaksanakan Rencana Aksi Pengembangan Ekonomi Kreatif sesuai dengan Strategi yang sudah di bangun.

Dengan demikian Kajian ini bertujuan untuk: 1) melihat dan mengklasifikasi dukungan Pemda Provinsi Jawa Barat dalam bentuk kebijakan seperti Peraturan Daerah (Perda), Peraturan Gubernur dan Keputusan Gubernur, serta bentuk kesiapan dan dukungan anggaran yang tertuang dalam APBDnya, 2) Mengidentifikasi dan menganalisis produk ekonomi kreatif bagi daerah Provinsi Jawa Barat terkait pelaksanaan rencana aksi pengembangan ekonomi kreatif, 3) Mengidentifikasi dan menganalisis potensi ekonomi kreatif Provinsi Jawa Barat terkait dengan Penyusunan rencana aksi pengembangan ekonomi kreatif, dan 4) Mengidentifikasi dan menganalisis permasalahan yang dihadapi daerah Provinsi Jawa Barat serta solusinya, terkait dengan pelaksanaan rencana aksi pengembangan ekonomi kreatif .

Sedangkan manfaat kajian adalah memberi masukan kepada pimpinan Kementerian Dalam Negeri dan Pemda guna mendorong Pemda Provinsi untuk menyusun dan melaksanakan rencana aksi pengembangan ekonomi kreatif.

Ada empat (4) hal yang sangat esensial dan perlu dijelaskan terkait dengan Kajian ini, yaitu: 1) kebijakan, 2). peningkatan peran pemerintah daerah, 3) Inpres sebagai suatu petunjuk pelaksanaan kebijakan,dan 4). ekonomi kreatif. Keempat hal ini merupakan landasan berpijak yang perlu dijelaskan dan diuraikan, sehingga baik dalam analisisnya maupun dalam menyusun instrumen penelitiannya dapat lebih fokus dilakukan.

Amara Raksasataya dalam Bintoro Tjokroamidjojo (1975) mengatakan: Kebijakan sebagai suatu taktik dan strategis yg diarahkan untuk mencapai suatu tujuan dan membentuk tiga (3) elemen penting, yaitu: a)Identifikasi dan tujuan yang ingin dicapai, b).Taktik atau strategi dari berbagai suatu taktik dan strategis tujuan yang diinginkan,dan c) Penyediaan berbagai input untuk memungkinkan pelaksanaan secara nyata dari taktik atau strategi.
Yang mengartikan secara bersamaan "public policy" atau Kebijakan Negara, yaitu: a) Thomas R. Dye (1978) mengatakan kebijakan negara adalah "whatever governments choose to do or not to do" mengandung maksud bahwa apabila pemerintah memilih untuk melakukan sesuatu atau tidak, ada tujuannya (obyektifnya) dan kebijakan negara itu harus meliputi semua tindakan pemerintah. b) Gerge C, Edwards dan Ira Sharkansky (1978) mengatakan "Is what government say and do,or not to do.Is is the goals purpose of government programs..." (...adalah apa yang dinyatakan dan dilakukan atau tidak dilakukan oleh pemerintah.Kebijakan negara itu berupa sasaaran atau tujuan program-program pemerintah....")

Bertitik tolak dari pengertian-pengertian "Policy" dan "Public Policy" seperti diutarakan maka dapat ditarik kesimpulan : 1)Pengertian policy atau kebijakan, lebih menekankan kepada policy atau kebijakan yang berlaku secara umum. Hal ini sesuai dengan pendapat Amara Raksasataya, dan 2) pengertian "Public Policy", yaitu "Kebijakan Negara". (Dye, Edwards dan Sharkansky) sangat tegas dan jelas yaitu: "Kebijakan Negara itu dapat ditetapkan dalam bentuk perundang-undangan atau dalam bentuk pidato-pidato pejabat teras (penting) Pemerintah ataupun berupa program-program dan tindakan-tindakan yang dilakukan oleh pemerintah.

Yang menjadi sorotan lebih jauh adalah Public Policy atau Kebijakan Negara, yakni: Serangkaian tindakan yang diwujudkan dalam suatu peraturan perundang-undangan dan turunan dari Undangundang untuk dilaksanakan atau tidak dilaksanakan oleh pemerintah untuk mencapai tujuan dan kepentingan seluruh masyarakat.

Mengacu pada rumusan di atas, ada tiga (3) hal penting sebagai intisari dari rumusan dimaksud, yaitu: 1). Serangkaian tindakan yang diwujudkan dalam bentuk taktik dan strategi yang ditetapkan dalam suatu peraturan perundang-undangan dan turunan dari peratruan perundang-undangan, 2) Pelaksanaan dari peraturan perundang-undangan dan turunannya, dan 3) Cakupan atau isi dari peraturan perundang-undangan dan turunannya.

Terkait dengan ketiga intisari ini, maka perlu ada ketatalaksanaan, yakni: sistem kerja dalam rangka penyelesaian suatu pekerjaan yang didalamnya memuat tata kerja dan prosedur kerja (LAN-RI, 1991), dengan memperhatikan asas-asas yang menjadi landasan dan pedoman pengaturannya,antara lain: 1).Harus didasarkan pada kebijakan yang berlaku (penyusunan dan pengaturan rangkaian tindakan dalam bentuk peraturan perundang-undangan dan turunannya, hendaknya selalu berpedoman pada kebijakan yang lebih tinggi untuk menjamin keserasiannya), 2) Kejelasan wewenang, tugas dan tanggung jawab setiap Aparatur yang terlibat. 3) Prinsip koordinasi, 4).Tertulis, 5).Disosialisasikan kepada semua pihak 
(stakeholder) dan 6) Kesederhanaan/tidak berbelitbelit

Secara normatif peran pemerintah daerah baik Provinsi maupun Kab/Kota telah diatur dalam UU No.32 Tahun 2004 tentang Pemerintah Daerah. Dalam Pasal 10 ayat (1) disebutkan: "Pemerintahan Daerah menyelenggarakan urusan pemerintahan yang menjadi kewenangannya...". Pengaturan lebih lanjut ditetapkan dalam Peraturan Pemerintah No.38 Tahun 2007 tentang Pembagian Urusan Pemerintah antara Pemerintah, Pemerintah Provinsi dan Pemerintah Daerah Kabupaten/Kota, Pasal 6 ayat (1) dan (2) serta Pasal 7 ayat (1),(2),(3), dan (4) menyebutkan secara rinci urusan pemerintahan yakni urusan wajib (ayat 2) dan urusan pilihan (ayat 4). Adapun urusan wajib terdiri dari 25 urusan, sedangkan urusan pilihan terdiri dari 8 urusan.

Terkait dengan Kajian yang dilakukan, sangat erat hubungannya dengan industri, sedangkan industri dimaksud adalah merupakan salah satu urusan pilihan daerah provinsi, kab/kota. Dalam perkembangannya kegiatan industri mempunyai dampak global, sehingga negara-negara maju menyebutnya industri kreatif, yang dalam perkembangannya menjadi salah satu andalan PDB sehingga disebut Ekonomi Kreatif.

Untuk memacu perkembangan industri, Pemerintah sejak Tahun 2005 memberikan perhatian yang lebih besar untuk lebih mengembangkan industri yang ada dengan mengandalkan sumberdaya insani yang kreatif untuk berinovasi, dan memberi peran kepada Pemerintah Daerah Provinsi, kabupaten/kota atas perannya yang sudah ada selama ini secara konvensional agar lebih meningkatkan peran dalam pelaksanaan Ekonomi Kreatif.

Dengan demikian, yang dimaksud dengan peningkatan peran Pemerintah Daerah dalam Kajian ini adalah "pemberian petunjuk, arahan dan pedoman kepada Pemerintah Daerah Provinsi,kabupaten dan kota,atas pelaksanaan urusan dibidang industri yang selama ini dilaksanakan secara konvensional untuk dikembangkan dan dikelola dengan melibatkan berbagai pihak terkait dengan menyusun dan menetapkan serta melaksanakan rencana aksi pengembangan Ekonomi Kreatif sebagaimana ditetapkan dalam Instruksi Presiden Nomor 6 Tahun 2009”.

Mengacu pada Undang-undang Nomor 10 Tahun 2004 tentang Pembentukan Peraturan Perundang-undangan, dalam Pasal 7 ayat (1) dikemukakan “ jenis dengan hirarki peraturan perundang-undangan “ adalah ,a).Undang-undang dasar Negara Republik Indonesia Tahun 1945,b).Undang-undang/Peraturan Pemerintah Pengganti Undang-undang, c)Peraturan Pemerintah, d)Peraturan Presiden, e)Peraturan Daerah.

Terkait dengan Undang-undang tersebut di atas, maka Instruksi Presiden Nomor: 6 Tahun 2009 tentang Pengembangan Ekonomi Kreatif, merupakan petunjuk pelaksanaan (Juklak) yang bersifat nasional dengan muatan sebagai berikut:

1. Jenis tugas/pekerjaan yang akan dilaksanakan yakni Pengembangan Ekonomi Kreatif

2. Yg ditugaskan melaksanakan: para Menteri, Gubernur,Bupati/Walikota seluruh Indonesia

3. Objek kegiatan yang akan dikembangkan yakni empat belas (14) sektor/sub-sub sektor yang meliputi: 1). Periklanan, 2). Asritektur, 3). Pasar seni dan barang antik, 4) Kerajinan, 5). Design, 6). Fashion (model), 7). Film, video dan fotografi, 8). Permainan interektif, 9). Musik, 10). Seni pertunjukan, 11). Penerbitan dan percetakan, 12). Layanan komputer dan piranti lunak, 13). Radio dan televisi, dan 14). Riset dan pengembangan.

4. Mempunyai sasaran ,arah, strategi Pengembangan Ekonomi Kreatif Tahun 20092015.

Departemen Perdagangan R.I pada tahun 2007 mendefinisikan industri kreatif di Indonesia sebagai "industri yang berasal dari pemanfaatan kreativitas, ketrampilan serta bakat individu untuk menciptakan kesejahteraan serta lapangan pekerjaan melalui penciptaan dan pemanfaatan daya kreasi dan daya cipta industri” (Kemendag, 2008). Namun, kehidupan di masa mendatang, tidak hanya dituntut bakat , tetapi juga harus mempunyai pola pikir. Howard Gardner (dalam Kemendag, 2008) mengatakan, bahwa terdapat lima (5) pola pikir yang diperlukan pada masa mendatang (five minds of the future), yaitu:

1. Pola Pikir Disipliner (the Disciplinary Mind), di sekolah, selain ilmu-ilmu seperti, matematika dan sejarah,saat ini harus menambah,bidang seni seperti disiplin ilmu lainnya.

2. Pola Pikir Mensintesakan (The Synthesizing Mind), Pola pikir sintesa melatih kesadaran untuk berpikir luas dan fleksibel, mau menerima sudut pandang dari multidisiplin.

3. Pola Pikir Kreasi (The Creating Mind), Dalam konteks desain, proses kreasi selalu diawali dengan pengumpulan permasalahan yang ada dan harus dapat dipecahkan. di akhir proses, akan dihasilkan desain-desain baru ; Dalam konteks bisnis, pola pikir kreasi ini, dapat menggerakkan perusahaan-perusahaan untuk lebih proaktif, tidak hanya mengikuti trend, tetapi justru menciptakan trend.

4. Pola Pikir Penghargaan (The Respectful Mind) yaitu kesadaran untuk mengapresiasi perbedaan diantara kelompok-kelompok manusia. Pola pikir seperti ini sangat dibutuhkan dalam menciptakan keharmonisan di dalam lingkungan.

5. Pola Pikir Etis (The Ethical Mind). Seorang warga negara yang baik, akan memiliki tanggung jawab moral yang tinggi, baik sebagai seorang pekerja maupun sebagai warga negara. Dalam konteks perubahan iklim dunia, 


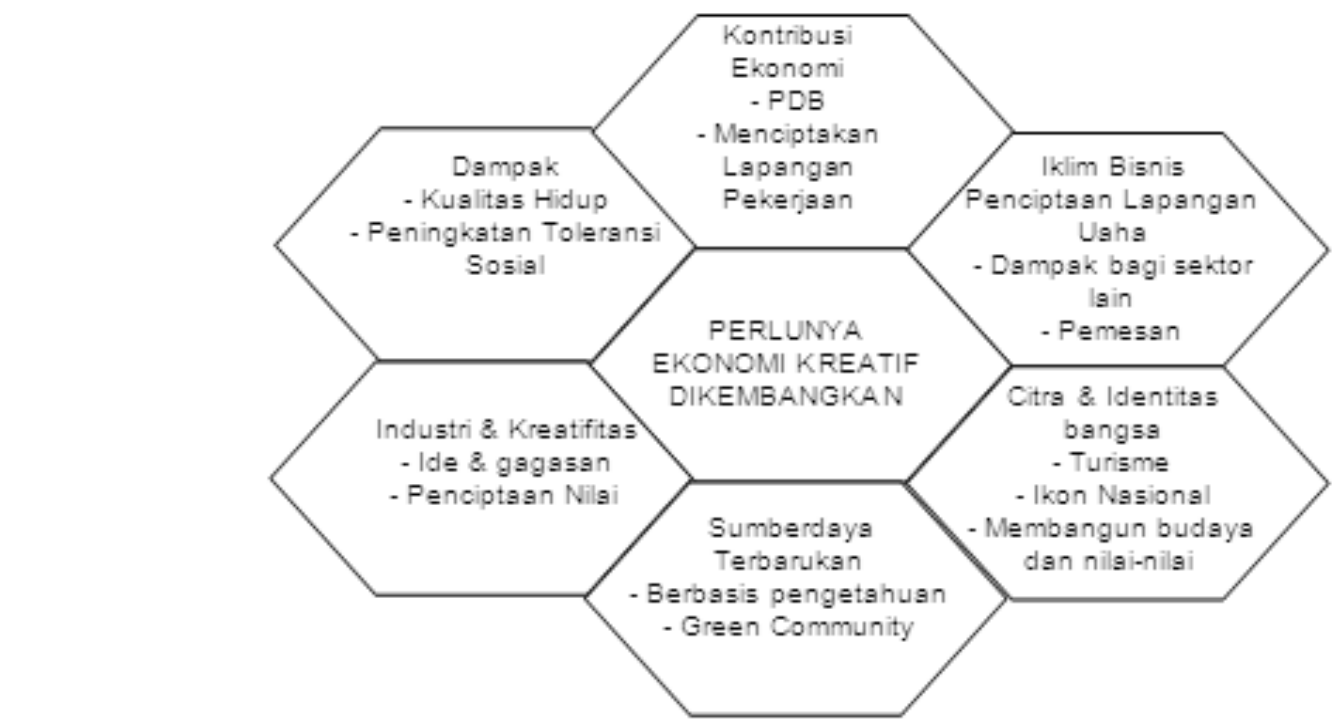

Sumber: Kementerian Perdagangan RI (2008)

Gambar 2: Perlunya Ekonomi Kreatif.

perekonomian nilai-nilai etika terhadap lingkungan dapat mendorong terciptanya produk yang ramah lingkungan, dan ia merasa malu bila ia meniru produk lain secara terangterangan.

Dengan demikian, dapat disimpulkan bahwa untuk menjadi pekerja kreatif tidaklah cukup memiliki bakat, pandai menggambar, menari, menyanyi dan menulis cerita, tetapi juga harus memiliki kemampuan mengorganisasikan ide-ide multi disipliner dan juga kemampuan memecahkan masalah dengan cara-cara diluar kebiasaan.

a. Perlunya Ekonomi Kreatif Dikembangkan Industri kreatif ini dapat memberikan kontribusi di beberapa aspek kehidupan, tidak hanya ditinjau dari sudut pandang ekonomi semata, tetapi juga dapat memberikan dampak positif kepada aspek lainnya..

Menurut Kemendag (2008) industri kreatif ini perlu dikembangkan, karena sektor ini memiliki kontribusi ekonomi yg signifikan bagi perekonomian Indonesia, dapat menciptakan iklim bisnis yang positif, dapat memperkuat citra dan identitas bangsa Indonesia, mendukung pemanfaatan sumberdaya yang terbarukan, merupakan pusat penciptaan inovasi dan pembentukan kreativitas, dan memiliki dampak sosial yg positif. Di bawah ini divisualisasikan "perlunya ekonomi kreatif dikembangkan".

b. Sektor Pengembangan Ekonomi Kreatif

Memperhatikan makna ekonomi kreatif, kemampuan yang dibutuhkan atau yang harus dimiliki dan pola pikir yang harus ditumbuh kembangkan dalam mendukung ekonomi kreatif, serta perlunya ekonomi kreatif dikembangkan di
Indonesia, maka visi ekonomi kreatif sampai dengan tahun 2025 adalah "Bangsa Indonesia Yang Berkualitas Hidup dan Bercitra di Mata Dunia". Sedangkan misinya adalah: "Memberdayakan Sumberdaya Insani Indonesia Sebagai Modal Utama Pembangunan Nasional

Terkait dengan misi ekonomi kreatif tersebut tampak bahwa sangat erat terkait dengan produk/jasa sebagai konstribusi dari industri kreatif. Adapun produk/jasa sebagai sektor atau subsektor pengembangan ekonomi kreatif itu (Kemendag 2008) sebanyak empat belas (14) produk/jasa, yaitu: (1) Industri Periklanan, yaitu : suatu kegiatan kreatif yang berkaitan jasa periklanan (komunikasi satu arah dengan menggunakan medium tertentu,(2) Industri Arsitektur, yakni: Jasa konsultasi arsitek yang mencakup usaha seperti: desain bangunan, pengawasan konstruksi perencanaan kota,(3) Industri Barang Seni, yakni: kegiatan yang berkaitan dengan perdagangan barang-barang seni asli (orisinil), unik dan langka dan berasal dari masa lampau (bekas) yang dilegalkan oleh undang-undang, dan memiliki nilai estetika seni yg tinggi,(4) Industri Kerajinan, yakni: Industri yang menghasilkan produk-produk, baik secara keseluruhan dengan tangan atau menggunakan peralatan biasa, peralatan mekanis. Produk kerajinan tersebut dibuat dari raw materials dalam jumlah yang tidak terbatas. Profesi-profesi dibidang industri kerajinan meliputi:a)Pembatik, (5) Industri Desain. Dalam kaitannya dengan ekonomi kreatif, akan dikembangkan dalam tiga kelompok disiplin ilmu desain, yaitu:a).Desain industri ,b) Desain Grafis/Desain Komunikasi Visual c). Desain Interior, (6) Industri Fesyen adalah kegiatan kreatif yang terkait dengan kreasi desain pakaian, dan desain asesories mode lainnya,(7) Industri Film, 


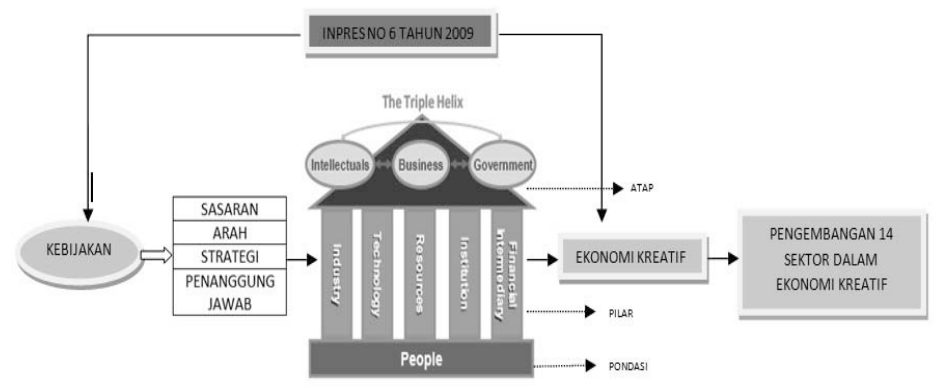

Gambar 3: Kerangka Pikir Kajian Ekonomi Kreatif (Pen. 2012)

Video dan Fotografi adalah kegiatan yang terkait dengan kreasi, produksi video, film dan jasa fotografi serta distribusi rekaman video,(8) Industri Permainan Interaktif adalah kegiatan kreatif yang berkaitan dengan kreasi, produksi dan distribusi permainan komputer dan video,(9) Industri Musik adalah kegiatan kreatif yang berkaitan dengan kreasi/ komposisi, pertunjukan musik, reproduksi dan distribusi dari rekaman suara,(10) Industri Seni Pertunjukan,Kegiatan ini berhubungan dengan seni drama, teater dan karawitan serta tari,(11) Industri Penerbitan dan Percetakan, meliputi kegiatan kreatif yang terkait dengan penulisan konten dan penerbitan buku, jurnal, Koran, majalah, tabloid,(12) Industri Layanan Komputer dan Piranti Lunak, yang meliputi kegiatan kreatif yang terkait dengan pengembangan teknologi informasi,(13) Industri Televisi dan Radio, yang berkaitan dengan usaha kreasi, produksi dan pengemasan, penyiaran dan transmisi televisi dan radio, dan (14) Industri Riset dan Pengembangan. Industri kreatif pada riset dan pengembangan meliputi kegiatan kreatif yang terkait dengan usaha inovatif yang menawarkan penemuan ilmu dan teknologi dan penerapan ilmu dan pengetahuan untuk perbaikan produk dan kreasi produk baru, proses baru, material baru, alat baru, metode baru dan teknologi baru yang dapat memenuhi kebutuhan pasar.

Ada 3 hal yang perlu untuk mengembangkan, model pengembangan ekonomi kreatif yaitu: (1)Pondasi industri kreatif,yaitu sumber daya insan Indonesia,dengan demikian menumbuhkembangkan pengetahuan dan kreativitas sumber daya insan inilah yang menjadi faktor produksi utama di dalam industri kreatif.

Richard Florida (2011) dalam Kemendag (2008) menyatakan bahwa ada tiga Strata Kreatif, yaitu:1)Inti Super Kreatif (Super Creative Core). , terdiri dari ilmuwan dan insinyur pada Universitas, pengarang cerita, seniman, dlldan lainnya yang secara intensif terlibat dalam proses kreatif., 2)Pekerja Kreatif Profesional (Creative Professional) seperti berbasis jasa layanan keuangan, berbasis hukum, praktisi kesehatan dan teknikal dan manajemen bisnis, dan 3).Strata pekerja yang pada umumnya memiliki gaji/upah yang kecil dan tidak memiliki otonomi dalam pekerjaannya. Seperti:, pekerja pembersih, pekerja administrasi, keamanan dan jumlahnya banyak. Agar Strata Kreatif berkembang lebih banyak dibanding strata pekerja, pemerintah harus lebih serius dalam mengembangkan sistem pendidikan yang mendukung lahirnya para pekerja kreatif, sehingga ekonomi kreatif yang merupakan ekonomi berbasis pengetahuan (knowledge economy) dapat tumbuh dan berkembang secara signifikan.

Selanjutnya terdapat lima (5) pilar, yang perlu terus diperkuat, sehinga industri kreatif dapat tumbuh dan berkembang mencapai Visi dan Misi ekonomi kreatif Indonesia,yaitu: (1) Industri. Industri merupakan bagian dari kegiatan masyarakat yang terkait dengan produksi, distribusi, pertukaran serta konsumsi produk atau jasa dari sebuah negara atau area tertentu., khususnya industri kreatif; (2). Teknologi. : teknik atau metode-metode atau aktivitas yang membentuk dan mengubah budaya teknologi ini dapat mewujudkan kreativitas individu dalam karya nyata; (3) Sumberdaya (Resources), merupakan input yang dibutuhkan dalam proses penciptaan nilai tambah, selain ide atau kreativitas yang dimiliki oleh sumber daya insani,juga sumberdaya alam/ ketersediaan lahan sebagai input penunjang dalam industri kreatf; (4) Institution, dalam pilar pengembangan industri kreatif dapat didefinisikan sebagai tatanan sosial,.seperti sistem nilai, adat istiadat atau norma, maupun formal dalam bentuk peraturan perundang-undangan. Industri kreatif memajukan ide-ide yang dapat dieksploitasi menjadi potensi ekonomi. Dengan demikian, peranan hukum dalam memproteksi ide-ide sangat penting, proteksi ide-ide dilaksanakan melalui mekanisme HKI. Namun, yang lebih penting adalah bagaimana insan Indonesia menggunakan proses kreatif di dalam kehidupan sehari-hari, baik secara keilmuan, industri maupun komersial, dan (5) Finance Intermediary, adalah lembaga yang berperan menyalurkan pendanaan kepada pelaku industri yang membutuhkan. modal/ekuitas, maupun pinjaman/kredit.

Dalam pengembangan ekonomi kreatif ada tiga (3) aktor yang saling berhubungan yakni Cendikiawan (Intellectuals), Bisnis (Business) dan Pemerintah (Government) yag disebut sebagai sistem "Triple Helix" (dalam Kemendag, 2008). 
Hubungan yang erat, saling menunjang dan bersimbiosis mutualisme antara ketiga aktor tersebut dalam kaitannya dengan landasan dan pilar model indutri kreatif (yang divisualisasikan dalam kerangka pikir) akan menghasilkan industri kreatif berdiri kokoh dan berkesinambungan. Kerangka pikir penelitian ini yang secara visual digambarkan pada gambar 3.

Kementerian Perdagangan RI telah melakukan studi banding ke tujuh negara, dua diantaranya dikemukana dibawah ini:

a. Konsep awal Malaysia adalah menggali dan menonjolkan identitas nasional budaya dan warisan budaya dan berkembang menjadi creative content, animation dll.Pemerintah sebagai aktor utama pengembangan ekonomi kreatif yang dipegang oleh Ministry,culture dan Horitage. Hal yang dapat dipelajari dari malaysia adalah pentingnya identitas nasional.

b. Pemerintah Thailand dalam mengelola industri kreatifnya dengan membentuk satu badan khusus yaitu TCDC dengan fokus desain.,yang melibatkan Kementerian di dalamnya seperti kementerian luar negeri,kementerian perindustrian dan kementerian perdagangan. Yang menjadi pembelajaran bagi indonesia adalah .Thailand menciptakan kemudahan akses utk mendapatkan "Source of capital" yang berdampak kepada peningkatan konsumsi dan pertumbuhan ekonomi

\section{METODE PENELITIAN}

Metode yang digunakan dalam Kajian ini adalah metode evaluasi formatif yaitu melihat dan mengkaji pelaksanaan serta program, mencari umpan balik untuk memperbaiki pelaksanaan program dimaksud, (Masri Sinagarimbun dan Sofian Efendi, 1987:5). yaitu hendak melihat dan menganalisis pelaksanaan pengembangan ekonomi kreatif di Provinsi Jawa Barat, sesuai dengan Inpres No.6 Tahun 2009, serta mencari umpan balik guna lebih bersinergi dalam pelaksanaannya.

Informan ditetapkan berdasarkan metode purposive sampling dengan pertimbangan tertentu yaitu: Satuan Kerja Perangkat Daerah (SKPD) mempunyai tupoksi: (1) bidang perencanaan pembangunan daerah, (2) menangani administrasi perekonomian daerah, (3) bidang perdagangan dan industri, (4) dan pelaku usaha. Lalu ditertapkan satu orang pejabat/staf dari Bappeda, Biro Perekonomian, Dinas Perdagangan dan Industri serta salah satu pelaku usaha ekonomi kreatif.

Untuk data sekunder, meminta secara langsung kepada SKPD Informan seperti Peraturan Daerah (Perda), Peraturan Gubernur, dan data lainnya yang terkait dengan pengembangan ekonomi kreatif. Data primer diperoleh langsung dari pejabat SKPD Informan melalui chechlist interview atau wawancara berdasarkan daftar check (tanda contreng),dengan menyediakan bahan wawancara dalam bentuk checklist yakni peneliti memberi tanda $(\sqrt{ })$ pada kolom yang disediakan dalam bahan wawancara dalam bentuk checklist yakni peneliti memberi tanda $(\sqrt{ })$ pada kolom yang disediakan dalam bahan wawancara.

lisis data dengan model Miles dan Huberman (dalam Sugiyono, 2008: 246-253) yaitu aktivitas dalam analisis data melalui /langkah sebagai berikut : (1) data reduction atau reduksi data, yaitu merangkum, memilih hal-hal yang pokok dan, penting saja terkait dengan pengembangan ekonomi kreatif, (2) data display (penyajian data),yaitu, penyajian (display) data dalam bentuk tabel, dengan demikian, data tersebut dapat tersusun dalam pola hubungan atau saling terkait, sehingga dapat membentuk pemahaman tentang pengembangan ekonomi kreatif dan (3) conclusion drawing (verification) Penarikan kesimpulan dan verifikasi, yang harus didukung data dan bukti-bukti lain yang valid dan konsisten. Melalui penarikan kesimpulan ini diharapkan dapat menjawab rumusan permasalahan.

\section{HASIL DAN PEMBAHASAN}

Provinsi Jawa Barat merupakan provinsi yang kaya raya akan keanekaragaman budaya dan manusia yang kreatif. Sebagai pusat pendidikan dengan ditunjang keberadaan berbagai R\&D centers,serta sebagai trendsetter berbagai industri seperti: pusat moda/fashion,musik dan perintis perfiliman, maka Jawa Barat dapat menarik generasi muda dari berbagai daerah sehingga dapat meningkatkan keanekaragaman potensi lokal ( diversity and variety of local potentials) yang kaya akan produk inovatif yang memiliki potensi ekspor. Dengan tersedianya potensi lokal yang tinggi sebagai pendukung industri kreatif,menjadikan Jawa Barat berkaitan erat dengan industri kreatif yang relevan dengan perkembangan ekonomi berbasis pengetahuan.

Kontribusi industri kreatif di Jawa Barat dari tahun 2001 hingga 2005 telah menyumbangkan ratarata $8 \%$ per tahun terhadap PDRB Jawa Barat dengan laju pertumbuhan pada tahun 2001-2005 sekitar 4,55\%. Mampu menyerap tenaga kerja sedikitnya 392.636 atau sekitar 2,54\% dari jumlah. Dengan otonomi daerah maka Pemerintah Jawa Barat dapat lebih leluasa dalam menyusun kebijakankebijakan yang berhubungan dengan industri kreatif.

Industri kreatif di Jawa Barat belum digali dan dikembangkan secara optimal sesuai potensi yang dimilikinya.termasuk menambah 1 sum sektor basis industri kreatif yaitu, Kuliner. Oleh karena itu Bappeda Provinsi Jawa Barat berinisiatif untuk membentuk suatu tim inisiasi (test force) yang terdiri dari berbagai pakar untuk membantu pemerintah Provinsi Jawa Barat dalam merumuskan strategi dan kebijakan pengembangan ekonomi kreatif sehingga 
Tabel .1 Rencana Strategis Pengembangan Industri Kreatif Jawa Barat

\begin{tabular}{|c|c|c|c|c|c|}
\hline \multicolumn{2}{|c|}{$2008-2010$} & \multicolumn{2}{|c|}{ 2011-2013 } & \multicolumn{2}{|c|}{$>2015$} \\
\hline $\begin{array}{c}\text { Rencana } \\
\text { Jangka } \\
\text { Penddek }\end{array}$ & $\begin{array}{l}\text { Hasil yang } \\
\text { diharapkan }\end{array}$ & $\begin{array}{c}\text { Rencana } \\
\text { Jangka } \\
\text { Menengah }\end{array}$ & $\begin{array}{l}\text { Hasil yang } \\
\text { diharapkan }\end{array}$ & $\begin{array}{c}\text { Rencana } \\
\text { Jangka } \\
\text { Panjang }\end{array}$ & $\begin{array}{l}\text { Hasil yang } \\
\text { diharapkan }\end{array}$ \\
\hline $\begin{array}{l}\text { - Peletakan } \\
\text { dasar industri } \\
\text { kreatif } \\
\text { - Identifikasi } \\
\text { potensi } \\
\text { industri } \\
\text { kreatif Jawa } \\
\text { Barat } \\
\text { - Penyusunan } \\
\text { kebijakan } \\
\text { industri } \\
\text { kreatif } \\
\text { (blueprint) }\end{array}$ & $\begin{array}{ll}\text { - Pembentukan } \\
\text { komisi kreatif } \\
\text { - Cetak biru } \\
\text { industri kreatif } \\
\text { - Statistik } \\
\text { industri kreatif } \\
\text { - Kebijakan } \\
\text { perijinan } \\
\text { - Paket kebijakan } \\
\text { keuangan } \\
\text { - Paket kebijakan } \\
\text { investasi } \\
\text { - Sosialisasi } \\
\text { industri kreatif } \\
\text { - Pembinaan } \\
\text { komunitas } \\
\text { kreatif }\end{array}$ & $\begin{array}{l}\text { - Peningkatan } \\
\text { permintaan } \\
\text { produk kreatif } \\
\text { - Peningkatan } \\
\text { investasi } \\
\text { dalam dan } \\
\text { luar negeri } \\
\text { - Pemantapan } \\
\text { pendidikan } \\
\text { dan pelatihan } \\
\text { pekerja untuk } \\
\text { industri } \\
\text { kreatif }\end{array}$ & $\begin{array}{l}\text { - Pasar kreatif: } \\
\text { ekspor dan } \\
\text { substitusi impor } \\
\text { - Ekspo industri } \\
\text { kreatif } \\
\text { - Duta Jabar } \\
\text { - Cinta produk } \\
\text { Jabar } \\
\text { - Konsorsium } \\
\text { pendidikan dan } \\
\text { pelatihan }\end{array}$ & $\begin{array}{l}\text { - Pemantapan } \\
\text { lebih lanjut } \\
\text { - Peningkatan } \\
\text { kemitraan } \\
\text { strategis } \\
\text { - Pencitraan } \\
\text { ikon nasional } \\
\text { industri } \\
\text { kreatif }\end{array}$ & $\begin{array}{l}\text { - Keunggulan } \\
\text { daya saing } \\
\text { Jabar } \\
\text { - Jabar ikon } \\
\text { nasional } \\
\text { - Penghargaan } \\
\text { kepeloporan } \\
\text { industri } \\
\text { kreatif }\end{array}$ \\
\hline
\end{tabular}

menjadi kekuatan ekonomi yang berdaya saing yang dapat diandalkan.

Terkait dengan Kebijakan Ekonomi Kreatif, Provinsi Jawa Barat telah membuat cetak biru industri kreatif di Jawa Barat. Konsep cetak biru adalah:

1. Apa impian bersama penduduk Jawa Barat? Mengembangkan visi bersama dan menerima pola pikir baru yang berdaya saing, kesejahteraan, produktivitas, penguasaan diri, dan kerendahan hati

2. Apa yang harus dilakukan untuk memastikan perubahan provinsi? Mengembangkan kesediaan untuk bertekad dan bersemangat demi keberhasilan perubahan provinsi.

3. Apa yang diharapkan terjadi sebagai keluaran dari perubahan?berusaha keras menoreh prestasi atau kontribusi atau mencapai target dalam segala aspek perubahan provinsi

4. Apa yang mesti dijaga agar hasil perubahan menjadi milik bersama? Meningkatkan kesejahteraan sosial dan menjunnjung keadilan sosial di provinsi.

Dibangunnya Visi bersama: Menjadikan Industri Kreatif sebagai media pembangunan SDM di Jawa Barat. Sumberdaya yang dimaksudkan adalah yang kreatif (melihat sesuatu yang baru), inovatif (mewujudkan produk/ jasa), dan produktif (memanfaatkan kesempatan).

Dibangunnya Komitmen bersama yaitu (1) Pembentukan forum industri kreatif Jabar: pemimpin kreatif, pewirausaha kreatif, komunitas kreatif, pekerja kreatif; (2) Peningkatan komunitas kreatif Jabar, (3) Pengembangan prasarana intelektual, (4) Pembangunan ekonomi a.l. dgn: penataan rantai nilai, peningkatan daya saing industri kreatif, peluang investasi \& sistem permodalan, (5). Peningkatan mutu pendidikan kreatif, (6) Ruang kreatif publik \& arsitektur kota,dan (7) Jejaring kota-kota kreatif jabar

Dibangunnya Instrumen pengembangan ekonomi kreatif di Jawa Barat yaitu: (1) Berbagi kepentingan: riset, informasi, dan forum, (2) Iklim bertumbuh: kebijakan industri kreatif, (3) Kompetensi: pengembangan SDM dan komunitas kreatif, (4) Sisi penawaran: kreasi, produksi, dan merk, (5) Sisi permintaan: komersialisasi, promosi, distribusi, dan edukasi dan (6) Tujuan: Produktivitas dan daya saing industri kreatif

Dibangunnya Arah kebijakan, yaitu: (1):

1. Menciptakan iklim yang mendorong kreatifitas a) Komisi Bandung atau Jabar kreatif,b).Pusat informasi industri kreatif (survey teratur) untuk mendukung riset dan pengembangan industri kreatif, c). Cetak biru pengembangan industri kreatif di Jawa Barat, d). Pengakuan kepeloporan dan prestasi dalam industri kreatif, e). Perlindungan hasil karya kreatif (hak cipta), f). Kemudahan perijinan usaha industri kreatif, g). Paket kebijakan keuangandan h). Paket kebijakan investasi (layanan informasi investasi yang berkualitas internasional)

2. Mengembangkan kemampuan penciptaan rantai nilai kreatif

a). Integrasi kegiatan kreatif, bisnis, dan teknologi, b). Relevansi lembaga pendidikan dengan bisnis kreatif, c). Layanan investasi yang berkualitas internasional, d). Akses modal kerja atau pembiayaan bisnis kreatif, e). Perlindungan terhadap karis pekerja kreatif dan penyetaraan gender 
Tabel 2. Draft Roadmap Pengembangan Ekonomi Kreatif Jabar

\begin{tabular}{lll}
\hline \multicolumn{1}{c}{ Bidang } & & \multicolumn{1}{c}{ Target 2012 - 2019 } \\
\hline Pengembangan & a. & Pengembangan pola relasi yang saling mendukung \\
Infrastruktur & b. Fasilitasi infrastruktur yan tepat \\
& c. Inisiasi pembentukan skema dan lembaga pembiayaan yang sesuai \\
Pendidikan dan Pelatihan & a. Fasilitasi creative talent untuk berkreasi bagi masyarakat \\
& b. Creative mindset programme kepada masyarakat \\
Pemasaran dan & c. Pelatihan dan pendampingan enterpreneurship \\
Komersialisasi & a. Penciptaan iklim kondusif bagi rantai nilai IK \\
Hukum dan Etika & b. Market attractiveness programme untuk keunggulan kompetitif \\
Penciptaan & a. Fasilitasi dan apresiasi terhadap nilai karya dan budaya \\
& b. Inventarisasi dan fasilitasi karya kreatif \\
Inovasi kelembagaan dan & c. Sosialisasi HKI dan etika penciptaan kepada masyarakat \\
Birokrasi & a. Creative mindset programme bagi pemangku kepentingan/ pemerintah \\
Riset dan Pengembangan & b. Program unggulan pemerintah berdasarkan kebutuhan yang strategis \\
Community Development & c. Aksi sebagai fasilitator meningkat dibanding mengedepankan birokrasi \\
& a. Program inovasi bermuatan lokal yang unggul \\
\hline
\end{tabular}

Sumber: Bappeda Jabar

3. Meningkatkan peluang atau permintaan terhadap produk kreatif

a). Expo industri kreatif, b). Kawasan atau pasar kreatif, c). Duta Bandung kreatif di mancanegara, d). Cinta budaya bangsa Keputusan Gubernur Jawa Barat No. 500/Kep.146-Bapp/2012

\section{Roadmap dan Orientasi Pencapaian Program Kerja}

Roadmap pengembangan ekonomi kreatif ini direncanakan untuk dilaksanakan sampai dengan RPJMD tahap ketiga yaitu sampai dengan tahun 2019. Keputusan Gubernur Jawa Barat No. 500/Kep.146-Bapp/2012 tentang Komite Pengembangan Ekonomi Kreatif Jawa Barat merupakan keputusan yang dibuat dengan memperhatikan Inpres No. 6 Tahun 2009 tentang Pengembangan Ekonomi Kreatif dan sebagai wadah yang dapat menjembatani serta memfasilitasi berbagai pemangku kepentingan ekonomi kreatif di Jawa Barat.

Tugas komite adalah menyusun kebijakan pengembangan ekonomi kreatif Jawa Barat dan mengawal pelaksanaan Rencana Aksi Pengembangan Ekonomi Kreatif Jawa Barat. komite mempunyai fungsi intermediasi pemangku kebijakan dan pelaku ekonomi kreatif serta para pihak yang berkepentingan untuk mengembangkan ekonomi kreatif Jawa Barat dan penguatan jaringan kerja dan koordinasi antarkomunitas kreatif setiap Kabupaten/Kota maupun dengan komunitas kreatif nasional dan internasional.

Pembiayaan kegiatan komite berasal dari APBD Provinsi Jawa Barat dan sumber lain yang sah dan tidak mengikat. Susunan personalia komite terdiri dari OPD yang terkait dengan ekonomi kreatif dan para pakar yang masuk dalam komisi. Pembina adalah gubernur dan Sekda Provinsi Jawa Barat.
Ketua komite adalah kepala Bappeda, Wakil ketua adalah Kepala Disperindag, Sekretaris Komite adalah Kabid Ekonomi pada Bappeda, dan anggota komite adalah Kepala Badan Koordinasi Promosi dan Penanaman Modal Daerah, Kadis. Pariwisata dan kebudayaan, Kadis Koperasi dan UKM, Kadis. Pendidikan, Kadis Permukiman dan Perumahan, Kadis. Komunikasi dan Informatika, dan Kabiro Administrasi perekonomian Setda Prov. Jabar .

\section{Rencana Aksi Pengembangan Ekonomi Kreatif di} Jawa Barat

Penjelasan menganai rencana aksi pengembangan ekonomi kreatif di Jawa Barat dimulai dari prioritas pembangunan daerah di Provinsi Jawa Barat. Berdasarkan common goals pembangunan daerah Provinsi Jawa Barat adalah sebagai berikut:

1. Peningkatan Kualitas Pendidikan,

2. Peningkatan Kualitas Kesehatan,

3. Peningkatan Daya Beli Masyarakat,

4. Kemandirian Pangan,

5. Peningkatan Kinerja Aparatur,

6. Pengembangan Infrastruktur Wilayah

7. Kemandirian Energi Dan Kecukupan Air Baku,

8. Penanganan Bencana Dan Pengendalian Lingkungah Hidup,

9. Pembangunan Perdesaan dan

10. Pengembangan Budaya Lokal Dan Destinasi Wisata

Pengembangan industri kreatif di Jawa Barat dikaitkan dengan common goals yang ke-3 yaitu peningkatan daya beli masyarakat. Pada common goals ke-3 tersebut dijabarkan lagi menjadi kegiatan tematik dan unggulan yang digambarkan pada tabel 3.

Output dari tematik 5 pengembangan industri kreatif dan wirausahawan muda kreatif berikut:1).Meningkatnya jumlah populasi pelaku usaha industri kreatif,2).Tumbuhnya wirausahawan 


\section{Tabel 3 Kegiatan Tematik dan kegiatan Unggulan pada Common Goals Peningkatan Daya Beli Masyarakat}

\begin{tabular}{|c|c|c|}
\hline No & Tematik & Kegiatan Unggulan \\
\hline 1 & $\begin{array}{l}\text { Peningkatan budaya masyarakat bekerja dan perluasan } \\
\text { lapangan kerja serta kesempatan berusaha UMKM }\end{array}$ & $\begin{array}{l}\text { a. Penumbuhan wirausaha baru dan penguatan wirausaha } \\
\text { melalui inkubasi bisnis } \\
\text { b. Peningkatan Produktivitas SDM Multisektor berstandar } \\
\text { Asean } \\
\text { c. Lapangan Kerja Baru dan Modal Usaha Melalui UKM } \\
\text { (Kerjasama dengan lembaga asuransi perkreditan) }\end{array}$ \\
\hline 2 & Jawa Barat sebagai daerah tujuan investasi & $\begin{array}{l}\text { a. Penyusunan Kebijakan Penanaman Modal dan Profil } \\
\text { Peluang Investasi di Jawa Barat } \\
\text { b. Fasilitasi dan koordinasi } \\
\text { c. pengembangan kawasan ekonomi khusus }\end{array}$ \\
\hline 3 & Pengembangan skema pembiayaan alternatif & $\begin{array}{l}\text { a. Fasilitasi Skema Pembiayaan alternatif Gemar, Gapura, } \\
\text { Gempita, KUMKM, melalui skema jaminan asuransi } \\
\text { modal usaha } \\
\text { b. Peningkatan Kapasitas dan Kapabilitas Lembaga } \\
\text { Keuangan Non Perbankan } \\
\text { c. Fasilitasi Pembentukan trust fund }\end{array}$ \\
\hline 4 & $\begin{array}{l}\text { Pengembangan agribisnis, forest bisnis, marine bisnis, } \\
\text { agroindustri, dan industri manufaktur }\end{array}$ & $\begin{array}{l}\text { a. Fasilitasi Peningkatan Sarana dan Prasarana Teknologi } \\
\text { Perikanan Tangkap } \\
\text { b. Fasilitasi Pengembangan Gerakan Multi Aktivitas } \\
\text { Agribisnis (GEMAR) } \\
\text { c. Fasilitasi peningkatan kompetensi SDM dan } \\
\text { pemberdayaan penyuluh pertanian, perkebunan, } \\
\text { peternakan dan kehutanan } \\
\text { d. Fasilitasi Gerakan Pengembangan dan Perlindungan } \\
\text { Pasar Tradisional (GEMPITA) } \\
\text { e. Dana Operasi Pasar Sembako }\end{array}$ \\
\hline 5 & $\begin{array}{l}\text { Pengembangan Industri Kreatif dan wirausahawan muda } \\
\text { kreatif }\end{array}$ & Fasilitasi pengembangan kawasan industri kreatif \\
\hline
\end{tabular}

Sumber: Bappeda Provinsi Jawa Barat

Tabel 4. Rincian Kegiatan Tematik Pengembangan Industri Kreatif dan Wirausahawan Muda Kreatif

\begin{tabular}{lll}
\hline No & \multicolumn{1}{c}{ Rincian Kegiatan Tematik } & OPD Penanggung Jawab \\
\hline 1 & Pengembangan Industri Kreatif berbasis IT & Dinas Indag \\
2 & Pengembangan Industri Fashion Muslim & Dinas Indag \\
3 & Membangun Jejaring Komunitas Kreatif & Dinas Indag \\
4 & Penumbuhan Wirausahawan Muda Berbasis Industri Kreatif & Dinas Indag, KUMKM \\
\hline
\end{tabular}

muda dibidang industri kreatif, 3). Bandung menjadi trendsetter Fashion Muslim Internasional dan 4).Tumbuhnya industri animasi, games, software dan film

Terdapat 4(empat) kebijakan dalam rencana aksi pengembangan industri kreatif di Jawa Barat, yaitu (1) Menciptakan infrastruktur yang memadai baik fisik, sosial dan hukum bagi pengembangan ekonomi kreatif, dengan strategi pencapaiannya dengan : (a) Membangun infrastruktur fisik berupa ruang publik sebagai penunjang aktivitas pelaku ekonomi kreatif, (b)Mempermudah akses pembiayaan terhadap pelaku ekonomi kreatif dan (c) Menjamin perlindungan hukum bagi produk kreatif Jawa Barat yang merupakan warisan budaya dan bagi pelaku ekonomi kreatif. (2) Mengembangkan sumber daya insan kreatif, (3) Memperkuat kerjasama antar pemangku kepentingan pelaku ekonomi kreatif dan (4) Meningkatkan dukungan terhadap riset dan pengembangan kreativitas dan inovasi. Masing-masing kebijakan ini diuraikan dalam strategi, program dan kegiatan berikut indikator kinerja sebagai alat mengukur tingkat pencapaian tujuan yang telah ditetapkan. .Rincian Kebijakan, strategi, program dan, kegiatan, indikator dan penanggungjawab kegiatan sebagaimana diuraikan dalam tabel terlampir.

\section{Pengembangan Industri Unggulan}

Provinsi Jawa Barat menentukan tiga subsektor unggulan yang akan dikebangkan di Provinsi Jawa Barat, yaitu kuliner, fesyen, dan kerajinan. Pemilihan 3(tiga) industri ini didasarkan atas pertimbangan hasil analisa sumbangsih nilai produk-produk tersebut terhadap PAD, PDRB, dan penyerapan tenaga kerja. Strategi pengembangan dan rencana aksi terhadap Industri unggulan dimaksud dapat diuraikan sebagai berikut: 
1) Industri kuliner. Pengembangan industri kuliner dilaksanakan dengan menetapkan sasaran jangka menengah dan sasaran jangka panjang. Sasaran jangka menengah antara lain Penambahan variasi dan cita rasa baru, sedangkan sasaran jangka panjangnya adalah Peningkatan volume dan variasi kuliner. Strategi pengembangannya antara lain, membentuk klaster industri kuliner untuk memudahkan kerjasama dan melakukan inovasi. Rencana Aksinya antara lain Memperkaya keanekaragaman kuliner dengan mengadakan pameran kuliner asli daerah secara rutin untuk memperkenalkan kuliner asli daerah dan mendorong para pelaku usaha membentuk komunitas sebagai wadah knowledge sharing dan networking. Strategi pengembangan dan rencana aksi lainnya lainnya dapat digambarkan dalam tabel terlampir.

2) Industri fesyen dan desain. Adapun sasaran jangka menengah Industri fesyen dan desain antara lain adalah ketersediaan bahan baku secara berkesinambungan terlebih bahan baku lokal,sedangkangkan sasaran jangka panjangnya antara lain adalah menghasilkan produk yang ramah lingkungan. Strategi pengembangannya antara lain adalah Bekerjasama dengan institusi pendidikan/ peneliti mengembangakan bahan baku substitusi untuk industri fesyen terlebih yang masih menggunakan bahan baku impor. Rencana aksinya antara lain adalah memperbaiki dan meningkatkan kualitas pelayanan terminal ekspor Jabar dengan memperbaiki dan melengkapi sarana prasarana terminal pelabuhan laut maupun udara serta membangun akses ke wilayah terminal. Strategi pengembangan dan rencana aksi lainnya lainnya dapat digambarkan dalam tabel terlampir.

3) Industri kerajinan: Adapun sasaran jangka menengah Industri kerajinan antara lain adalah Mengolah dan memanfaatkan bahan baku alam tanpa merusak ekosistem alam sedangkangkan sasaran jangka panjangnya antara lain adalah Memiliki fasilitas pengolahan kembali limbah produksi. Strategi pengembangannya antara lain xxxMembentuk kelompok kerjasama para pelaku. Rencana aksinya antara lain adalah Mengembangkan lembaga sertifikasi kerajinan. Strategi pengembangan dan rencana aksi lainnya dapat digambarkan dalam tabel terlampir.

\section{Profil Ekonomi Kreatif}

Seiring dengan pertumbuhan ekonomi, yang tadinya berbasis Sumber Daya Alam ( SDA), sekarang menjadi berbasis SDM, dari era pertanian ke era ekonomi dan informasi. Industri kreatif , diartikan sebagai kumpulan aktifitas ekonomi yang terkait dengan penciptaan atau penggunaan pengetahuan dan informasi.Industri kreatif juga dikenal dengan nama lain Industri Budaya atau Ekonomi kreatif.

Selain 14 sub sektor yang menjadi basis industri kreatif sebagaimana yang dipetakan oleh
Kementerian Perdagangan,di Jawa Barat menambah 1 sub sektor lagi yaitu KULINER.Sehingga di Jawa Barat sub sektor industri kreatif menjadi 15. Kuliner yaitu pusat produk makanan olahan khas Indonesia yang perlu disebarluaskan melalui media yang tepat di dalam dan di luar negeri,sehingga memperoleh peningkatan daya saing di pasar ritel modern dan pasar internasional.

Kelompok usaha di Jawa Barat sangatlah beragam,baik yang formal maupun non formal . Tumbuh dan berkembang atas komunitas pelaku usaha mandiri Seiring dengan maraknya program pemerintah dari tingkat pusat ke daerah, pembentukan kelompok usaha dilakukan mulai dari tingkat RT /RW bahkan nasional, kemudian berkembang menjadi wirausahawan. Intinya wirausahawan harus memiliki kemampuan berpikir kreatif-imajinatif dalam melihat, menciptakan dan menemukenali peluang bisnis yang baru.

\section{Profil Industri Kreatif di Beberapa Kabupaten/ Kota di Jawa Barat}

Penelitian pernah dilakukan oleh CIEL SBM ITB di 11 kabupaten/kota / kota di Jawa Barat seperti: 1) Bandung ( sector industry fashion dan desain ,yang masih perlu pembinaan ), 2). Bogor: ( kuliner dan fashion,perak, Wayang ), 3)Ciamis(industry disain dan kuliner), 4)Cirebon(kerajinan), 5)Garut (Kerajinan dan Fashion), 6)Kuningan (kuliner dan Kerajinan), 7).Tasikmalaya(kerajinan border dan fashion,desain dan arsitektur), 8)Bekasi(industry rumah tangga:lkrajinan bunga,boneka), 9)Karawang (Industri pengolahan,pariwisata, tanaman pangan,perikanan darat), 10).Purwakarta( Kerajinan keramik ), 11) Subang( Kuliner,industry kerajinan).

\section{Urutan Subsektor Industri Kreatif di Jawa Barat}

Dari berbagai sub sector industry di Jawa Barat, terdapat sub sector dari yang dominan sampai terendah yaitu: $\operatorname{Kerajinan}(27,7 \%)$, fasion $(15,3 \%)$, desain $(14,6 \%)$, kuliner ( $14,6 \%)$ arsitektur ( $4 \%)$, Visual art (3\%), turism, seni, patung dan film ( $2 \%$ ). Di urutan terakhir yaitu teater, multimedia, games interaktif, layanan computer dan piranti lunak ( 1\%)

Berdasarkan hasil wawancara dengan para informan dan pelaku industri dapat digambarkan secara singkat kondisi industri kreatif di Provinsi Jawa Barat sebagai berikut: Kondisi kreatifitas di Jawa Barat sudah maju, ekonomi kreatif muncul dari kreatifitas masyarakat, pemerinth hanya fasilitasi. Kondisi ini didukung oleh banyaknya perguruan tinggi dan anugerah seni budaya dari leluhur. Di masyarakat telah berkembang komunitas-komunitas yang sudah ada jauh sebelum terbitnya Inpres No 6 tahun 2009. Pembinaan oleh pemerintahpun tidak seperti pembinaan pada pengusaha biasa, karena kreatifitas telah berkembang sendiri. Bahkan para ahli dari Jabar (Prof. Togar dari ITB) diminta untuk membuat cetak biru oleh Kementerian Perdagangan. 
Pengembangan industri kreatif melibatkan banyak OPD yaitu Biro administrasi dan perekonomian, Bappeda, Dinas Perindustrian dan Perdagangan. Biro perekonomian bersifat koordinatif terhadap semua pihak yang terlibat dan fasilitasi kegiatan-kegiatan yang akan diselenggarakan oleh instansi teknis. Bappeda melaksanakan perencanaan dengan memasukkan perencanaan terkait Ekonomi Kreatif dan menginisiasi pembentukan komite Ekonomi kreatif sebagai tempat berkumpul untuk merencanakan pengembangan Ekonomi Kreatif di Jabar serta menyusun kebijakan terkait dan mengawal rencana aksi pengembangan nya. Sementara urusan teknis rencana aksi pengembangan ekonomi kreatif dilaksanakan oleh berbagai OPD seperti Disperindag, Dinas Pariwisata dan Kebudayaan, Dinas Pendidikan, dan Dinas PU dan Permukiman. Salah satu contoh gerak Dinas KimRum adalah membuat ruang terbuka publik di 4(empat) kab/kota untuk pengembangan ekonomi kreatif.

Jika dilihat dari kondisi paling maju dalam hal dukungan dan komitmen Pemda adalah Kota Bandung dan Cimahi, karena sampai dimasukkan ke kurikulum pendidikan. Yang paling menonjol di Jabar adalah fesyen, animasi, kerajinan, IT, iklan. Yang paling maju khususnya di Kota Bandung adalah fashion, karena didukung oleh kebiasaan berpakaian masyarakat yang bangga dengan kreasi rekan/ lingkungan sendiri.

Pendanaan oleh APBD mulai dari inventarisasi masuk di Bappeda, di biro perekonomian hanya ada dana-dana koordinasi. Sangat diuntungkan bahwa ekonomi kreatif ditempatkan di Bappeda karena terkait program dan penganggaran. Penganggaran belum khusus bernama kegiatan ekonomi kreatif, karena belum ada petunjuk untuk membuat hal itu. Ada wacana bahwa jika dikhususkan tentang industri kreatif maka bisa double counting dengan sektor lain karena industri kreatif bisa masuk di sektor manapun. Contoh: perkembangan brownis saat ini termasuk industri kreatif tapi dihitung pada industri makanan. Jadi harus sangat hati-hati dalam mendefinisikan dan memisahkan kegiatan ekonomi kreatif.

Beberapa permasalahan terkait pengembangan ekonomi kreatf diantaranya:

1. Saat ini belum ada profil ekonomi kreatif karena belum dilakukan perhitungan sektor industri kreatif karena sulit sekali mengindentifikasi secara rigid mana industri kreatif dan definisi kreatif.

2. Kondisi infrastruktur di masing-masing Kabupaten/Kota masih perlu ditingkatkan.

3. Terlihat di Kota Bandung adalah kemacetan akibat industri fesyen yang maju pesat.

4. Masalah industri kreatif: pendanaan belum terealisasi semua, HAKI, perijinan, promosi, dan permodalan
Kondisi pengembangan industri kreatif sangat butuh komitmen pimpinan daerah. Tataran kebijakan di provinsi sudah dilaksanakan, tapi di Kabupaten/kota belum. Butuh peran Kemendagri untuk pelaksanaannya. Disarankan Kemendagri menulis surat ke Kab/Kota agar segera melaksanakan amanat Inpres No. 6 Tahun 2009 dan segera menyelenggarakan evaluasi pelaksanaannya. Peran serta pemerintah dalam pengembangan ekonomi kreatif juga tidak bisa disamakan dengan perannya terhadap kebijakan lainnya.

Pelaku usaha jika terlalu banyak diintervensi oleh pemerintah kondisi kreatifitasnya menjadi terbatas, pemerintah sebaiknya hanya berperan pada regulasi perijinan, tempat usaha, dan regulasi pajak. Pendanaan biasanya hanya untuk pelatihan-pelatihan terutama dalam hal administrasi. Peran pemerintah bukan dalam pengembangan kreatifitas tapi menciptakan kondisi bagaimana usaha tetap bisa berjalan seperti sertifikat halal, ijin Depkes, BPOM, HAKI, dan manajemen usaha.

Salah satu peran pemerintah juga adalah pemberian apresiasi seperti adanya acara Baksia Caraka anugerah dari pemerintah pusat untuk $\mathrm{Kab} /$ Kota yang sangat mendukung ekonomi kreatif di daerah. Tahun ini Jabar mengirim 5 wakil yaitu Kota Bandung, Cimahi, Bandung Barat, Sukabumi, dan Depok

\section{Kebijakan Industri Kreatif di Provinsi Jawa Barat}

Menurut pemda keberadaan inpres No. 6 Tahun 2009 Tentang Pengembangan Ekonomi Kreatif sangat baik karena setiap instansi pemerintah yang tercantum dalam inpres tersebut wajib membuat rencana aksi berupa program dan kegiatan pengembangan ekonomi kreatif serta bersama-sama menghasilkan program tahun Indonesia Kreatif 2009. Inpres tersebut juga sebagai pedoman dalam pengembangan industri/ ekonomi kreatif di Indonesia. Inpres ini sudah disosialisasikan di Provinsi Jawa Barat. Penyelenggaranya dari Disperindag dan Biro Ekonomi Prov. Jabar. Sosialisasi tingkat Kabupaten/ Kota juga diselenggarakan di Kota Bandung dan Kota Cimahi.

Inpres No. 6 Tahun 2009 sudah ditindaklanjuti oleh Pemda Provinsi Jawa Barat dengan Kepgub No. 500/Kep 146-BPP/2012 tentang Komite Pengembangan Ekonomi Kreatif Jawa Barat. Keputusan ini merupakan pedoman kebijakan pengembangan ekonomi kreatif Jabar dan mengawal pelaksanaan rencana aksi pengembangan ekonomi kreatif Jabar. Tetapi sampai sejauh ini muatan kebijakan yang tercantum belum dilaksanakan, disarankan difasilitasi oleh pusat dalam hal ini Kemendagri.

"Leading sector" pelaksanaan Inpres No. 6 Tahun 2009 adalah Bappeda dan Disperindag Provinsi Jabar. Sesuai tupoksinya Bappeda Prov. Jabar menyelenggarakan komunikasi dan 
sinkronisasi perencanaan pembangunan daerah dengan nasional serta Kabupaten/Kota. Selain itu pelaksanaannya melibatkan Dinas pariwisata dan kebudayaan Prov. Jabar, Dinas Pendidikan, dan Dinas Pemukiman dan Perumahan.

Provinsi Jawa Barat telah siap melaksanakan Inpres No. 6 Tahun 2009 Tentang Pengembangan Ekonomi Kreatif karena sudah ada SKPD atau wadah lain sebagai pelaksana, sudah ada dana/ anggaran yang disediakan dalam APBD setiap tahun, dan ada SDM yang mendukung pelaksanaannya. Tetapi masih diperlukan peningkatan komitmen dalam pelaksanaan pembinaan industri kreatif khususnya dalam dukungan dana/ biaya.

Permasalahan yang dihadapi Pemda pelaksanaan pengembangan industri kreatif :

1. Tidak memiliki peraturan yang mengatur manajemen hak atas kekayaan intelektual, terlihat dari banyaknya pelanggaranpelanggaran terhadap hasil kreatifitas

2. Masih tumbuh budaya yang tidak kreatif (budaya ikut-ikutan, negatif thinking)

3. Kegiatan kreatif masih terkotak-kotak dan belum ada kajian rantai nilai yang utuh mulai dari kegiatan kreasi, produksi, dan distribusi.

4. Masalah pendanaan/ biaya

5. Masalah pendataan industri-industri kreatif

6. Masalah permodalan di para pelaku usaha

7. Masalah kemitraan dalam dukungan promosi dan bahan baku

8. Keterbatasan infrastruktur ruang publik yang berpotensi untuk sumber inspirasi, ekspresi, produksi, dan apresiasi

9. Masih banyak kesulitan para pelaku kreatif dlm mengurus perijinan,perlu dukungan

10. Belum dirasakan adanya sinkronisasi program kreatif dari provinsi dengan Kabupaten/Kota

11. Belum adanya diklat yang materinya benarbenar dibutuhkan oleh pelaku kreatif

Solusi dari pemecahan permasalahan di atas diantaranya adalah:

1. Membangun kemampuan SDM melalui workshop, pelatihan, dan pendidikan

2. Mengembangkan ekosistem bisnis yang terpadu

3. Implementasi dari model pengembangan industri kreatif

4. Perindungan dan manajemen, dukungan hak atas kekayaan intelektual (HAKI)

5. Membangun hubungan dengan komunitas kreatif (Bandung Creative City Forum dan Cimahi Creative Comunity)

6. Perlu adanya dukungan pendanaan dari pemerintah provinsi atau pemerintah pusat

7. Perlu adanya dukungan dana untuk pendataan industri kreatif di Jabar

8. Perlu diperbanyak even-even/ kegiatan pameran atau E-Commerce untuk pemasaran produk industri

9. Ruang publik pelaku kreatif dengan lokasi di 4 kab/Kota dalam
10. Perijinan dipermudah

11. Menfasilitasi diklat pelaku ekonomi kreatif yang diselenggarakan oleh dinas perindag dan dinas pendidikan

\section{Pengembangan Industri Kreatif Jawa Barat}

Pengembangan industri kreatif di Jawa Barat meliputi 14 (empat belas) sub sektor ditambah sub sektor kuliner. Yang paling menonjol khususnya di Kota Bandung adalah Fesyen. Kerajinan banyak berkembang di wilayah priangan. Kerajinan yang berkembang adalah anyaman dan kayu. Lukisan berkembang di Kab. Bandung di Desa Jelekong dengan media kanvas. Lukisan ini bahkan sering dibeli langsung oleh pedagang Malaysia untuk diperjualbelikan kembali. Industri furniture banyak berkembang di Cirebon dan Sumedang. Bahan baku yang digunakan masih cukup tersedia dari bahan baku lokal.

Pemasaran produk industri kreatif tersebut biasanya melalui toko-toko besar di kota dan di luar kota atau pusat-pusat perdagangan besar, pemasaran melalui on-line/web (internet Marketing), pemasaran melalui pameran-pameran/ promosi, bazar, dan pemasaran antar teman (mouth to mouth).

Kondisi perbankan mendukung keberadaan industri kreatif, tetapi masih jarang dimanfaatkan oleh pelaku industri kreatif, karena banyak industri kreatif yang masih belum bankable terkait perijinan usaha khususnya industri yang berskala kecil. Perlu dukungan/ peran pemerintah dalam masalah perizinan usahanya.

\section{Kondisi Pelaku Industri Kreatif di Provinsi Jawa Barat}

Hartawan Harun, pemilik usaha rumah kebaya bordir dengan nama Tafali Bordir.

Usaha telah dimulai 14 tahun yang lalu. Awalnya pegawai Cuma 11 orang, sekarang menjadi 21 orang. Produksi di Tasikmalaya dan pegawai asli berasal dari Tasikmalaya sendiri yang sudah punya kemampuan membordir secara turun menurun.. Cara meningkatkan keterampilan pegawai baru, dengan memberikan pekerjaan dengan bahan murah terlebih dahulu sehingga bisa dijual murah seiring waktu dan jika dilihat kemampuan sudah meningkat maka baru diberi bahan yang mahal. Saat ini upah pekerja lebih kurang 600 ribu per potong kebaya. Upah ini mungkin di atas rata-rata, buktinya tidak ada pekerja yang keluar selama dipekerjakan.

Bahan baku masih total dari dalam negeri, biasanya dari supplier sutera Garut. Jenis bordir yang ada saat ini adalah bordir komputer, mesin dinamo (Juki), dan mesin halus. Dengan komputer produksi bisa massal (banyak) tetapi hal ini mematikan daya kreatifitas maupun kuantitas tenaga manusia. Selain itu dengan komputer memiliki kelemahan jika satu jahitan benang terputus maka bordir akan terlepas semua. Dengan mesin Juki pengerjaan 1 potong kebaya makan waktu 2 hari, 
sementara dengan mesin halus memakan waktu lebih kurang 2 minggu. Desain asli kreatifitas sendiri dibantu istri. Inspirasi bisa datang dari desain batik pasangan kebaya , dimodifikasi dengan menerapkan ke kain kebaya.

Permodalan dari pribadi karena ,takut dikejar bunga hutang. Tapi saat ini sangat terbantu, karena menjadi mitra binaan Telkom sudah 3 periode (1 periode 2 tahun). Bentuk binaannya harus meminjam uang tetapi dengan bunga yang sangat ringan. Fasilitas yang diberikan adalah promosi secara rutin dengan seluruh biaya transportasi dan akomodasi ditanggung oleh pihak telkom.

Upaya pemasaran sedang merambah kerjasama dengan kantor-kantor pemerintah dan sangat berharap agar keluar SE Gubernur tentang pemakaian seragam dengan unsur bordir. Pemasaran saat ini masih mengandalkan promosi dari mulut ke mulut dan pameran. Belum ada jalur untuk ekspor. Selama ini kemungkinan barang sudah dibawa keluar negeri dari tangan ke tangan tapi tidak langsung memasarkan sendiri ke luar negeri. Fasilitasi dari pemda pada saat pameran biasanya hanya menyediakan stan tanpa akomodasi sehingga banyak pengusaha yang masih berat untuk ikut. Sementara jika dimotori oleh BUMN/D seluruhnya ditanggung. Maka yang perlu dilakukan pemerintah adalah menggerakkan BUMN/D yang belum berperan dalam mendukung industri kreatif.

\section{Pembahasan}

\section{Dukungan dan Kesiapan Provinsi Jawa Barat dalam Pengembangan Ekonomi Kreatif.}

Dari gambaran yang sudah dipaparkan, Pemerintah Provinsi Jawa Barat sangat mendukung pengembangan ekonomi kreatif di wilayahnya, bahkan sudah dilaksanakan sebelum terbitnya Inpres No 6 tahun 2009 tentang Pengembangan Ekonomi Kreatif. Inpres No. 6 Tahun 2009 Tentang Pengembangan Ekonomi Kreatif sendiri sudah disosialisasikan di Provinsi Jawa Barat. Penyelenggaranya dari Disperindag Prov. Jabar dan Biro Ekonomi Prov. Jabar. Sosialisasi tingkat Kabupaten/ Kota juga diselenggarakan di Kota Bandung dan Kota Cimahi.

Pemda Provinsi Jabar telah sangat siap melaksanakan amanat inpres tersebut. Hal ini dibuktikan dengan adanya kebijakan-kebijakan yang telah dikeluarkan oleh Pemda terkait hal tersebut. Meskipun kebijakan-kebijakan ini keluar setelah adanya Inpres No 6 Tahun 2009 tentang Pengembangan Ekonomi Kreatif, namun latar belakang dikeluakannya kebijakan tidak sematamata karena adanya Inpres, tapi karena pemerintah telah menyadari sepenuhnya akan potensi ekonomi kreatif di wilayahnya yang sangat besar sehingga diharapkan mampu mendorong pembangunan ekonomi Jawa Barat secara umum. Kebijakan yang telah dikeluarkan oleh Pemda Provinsi Jawa Barat berupa Cetak Biru Rencana Pengembangan Industri Kreatif Jawa Barat, terbitnya Keputusan Gubernur Jawa Barat No. 500/Kep.146-Bapp/2012 tentang Komite Pengembangan Ekonomi Kreatif Jawa Barat, dan adanya Rencana Aksi Pengembangan Ekonomi Kreatif di Jawa Barat.

Cetak Biru Rencana Pengembangan Industri Kreatif Jawa Barat yang telah dibuat sudah cukup lengkap memuat visi bersama, komitmen bersama, instrumen pengembangan ekonomi kreatif, arah kebijakan, rencana strategis pengembangan ekonomi kreatif, roadmap dan orientasi pencapaian program kerja dalam rangka pengembangan ekonomi kreatif. Cetak biru ini telah disusun berdasarkan tahapan jangka pendek, menengah, dan jangka panjang yang diharapkan dapat mempermudah dalam setiap pelaksanaanya.

Keputusan Gubernur Jawa Barat No. 500/Kep.146-Bapp/2012 tentang Komite Pengembangan Ekonomi Kreatif Jawa Barat merupakan salah satu bentuk komitmen Pemda Provinsi Jabar dalam melaksanakan amanat Inpres No. 6 Tahun 2009 tentang Pengembangan Ekonomi Kreatif. Komite ini dibuat dengan melibatkan seluruh perwakilan stakeholder yang terkait dengan ekonomi kreatif. Selain berperan dalam membuat dan mengawal kebijakan, komite ini juga dibentuk sebagai wadah yang menjembatani stakeholder/ pelaku ekonomi kreatif untuk dapat berperan secara optimal dalam pengembangan ekonomi kreatif. Tetapi karena relatif baru, keputusan gubernur tersebut belum dilaksanakan sepenuhnya.

Rencana aksi pengembangan ekonomi kreatif di Jawa Barat telah disusun dan disesuaikan dengan perencanaan pembangunan di Provinsi Jawa Barat sehingga terbentuk rangkaian dan ada benang merah antara pengembangan ekonomi kreatif dan pembangunan Jawa Barat secara umum . Dalam prioritas pembangunan daerah/ common goals pembangunan daerah terdapat tujuan peningkatan daya beli masyarakat. Dalam common goals tersebut dijabarkan lagi menjadi kegiatan tematik dan unggulan pengembangan industri kreatif dan wirausahawan muda kreatif dengan menfasilitasi pengembangan kawasan industri kreatif. Setelah itu disusun kebijakan dan rencana aksi pengembangan industri kreatif di Jawa Barat yang disusun detail dijabarkan menjadi strategi, program, kegiatan, indikator kinerja, dan penanggungjawab masingmasing kegiatan. Selain itu, Provinsi Jawa Barat telah menetapkan subsektor unggulan yang akan dikebangkan di Provinsi Jawa Barat, yaitu kuliner, fesyen, dan kerajinan. Dari masing-masing subsektor tersebut disusun sasaran, strategi pengembangan, dan rencana aksi pengembangan masing-masing subsektor.

Kesiapan Provinsi Jawa Barat dalam pengembangan ekonomi kreatif selain dari sisi kebijakan, juga bisa dilihat dari sisi SDM sebagai pondasi utama model pengembangan ekonomi 
kreatif dan dari sisi pendanaan. Dari sisi SDM, Jawa Barat mempunyai sumberdaya kreatif yang berasal dari kemampuan turun temurun insan Jawa Barat sesuai dengan budaya yang berkembang di Jawa Barat dan juga didorong oleh kreatifitas para pendatang di Jawa Barat. Dari sisi pendanaan, pendanaan pengembangan ekonomi kreatif didanai oleh APBD. Pendanaan oleh APBD mulai dari inventarisasi dan dana komite pengembangan ekonomi kreatif masuk di Bappeda. Selain itu ada dana terkait koordinasi di biro perekonomian. Sangat diuntungkan bahwa ekonomi kreatif ditempatkan di Bappeda karena terkait program dan penganggaran.

Peran serta pemerintah dalam pengembangan ekonomi kreatif juga tidak bisa disamakan dengan perannya terhadap kebijakan lainnya. Pelaku usaha jika terlalu banyak diintervensi oleh pemerintah kondisi kreatifitasnya menjadi terbatas, pemerintah sebaiknya hanya berperan pada regulasi perijinan, tempat usaha, dan regulasi pajak. Pendanaan biasanya hanya untuk pelatihan-pelatihan terutama dalam hal administrasi. Peran pemerintah bukan dalam pengembangan kreatifitas tapi menciptakan kondisi bagaimana usaha tetap bisa berjalan.

\section{Potret Ekonomi Kreatif dan Permasalahan yang dihadapi dalam Pengembangannya.}

Potret lengkap kondisi ekonomi kreatif di Jawa Barat telah digambarkan pada bagian terdahulu. Beberapa hal penting yang dapat dicermati dari kondisi ekonomi kreatif di Jawa Barat adalah:

a. Berkembangnya industri kreatif di Jawa Barat diawali dengan tumbuhnya kelompok usaha mandiri di masyarakat karena mereka menikmati ikatan yang saling bekerja sama untuk memenuhi kebutuhan dasar. Kelompok ini kemudian berkembang menjadi wirausahawan-wirausahawan yang pandai dan berbakat mengenali produk baru, menyusun cara baru dalam berproduksi, menyusun operasi untuk pengadaan produk baru, mengatur permodalan operasinya serta memasarkannya.

b. Perkembangan ekonomi kreatif di Jabar bisa jadi karena di Jawa Barat mempunyai keunggulan/ potensi kreatif yang tidak dimiliki oleh provinsi lain. Beberapa diantaranya adalah:

1) Dari sisi individu kreatif Jawa Barat dikaruniai individu kreatif yang didukung oleh warisan budaya yang beranekaragam dan masih terpelihara di masyarakat.

2) Pada sisi geoculture, Jabar sangat stretegis dan diuntungkan dengan jarak dengan Jakarta sebagai pusat pemerintahan dan perdagangan. Salah satu karakter Jabar dan masyarakatnya adalah terbuka dengan berbagai perkembangan dan kemajuan.

3) Jabar sebagai pusat pendidikan, khususnya Kota Bandung terdapat perguruan tinggi yang memberikan pendidikan yang berpengaruh pada kreatifitas SDM.

4) Berkembangnya sektor pariwisata di Jawa Barat sangat mendukung keberadaan ekonomi kreatif.

c. Provinsi Jawa Barat menentukan tiga subsektor unggulan yang akan dikebangkan di Provinsi Jawa Barat, yaitu kuliner, fesyen, dan kerajinan. Pemilihan 3(tiga) industri ini didasarkan atas pertimbangan hasil analisa terhadap kondisi dan potensi ekonomi daerah seperti sumbangsih nilai produk-produk tersebut terhadap PAD, PDRB, dan penyerapan tenaga kerja.

d. Selain 14 sub sektor yang menjadi basis industri kreatif sebagaimana yang dipetakan oleh Kementerian Perdagangan,di Jawa Barat menambah 1 sub sektor lagi yaitu KULINER. Jawa Barat memiliki warisan budaya produk makanan khas yang pada dasarnya merupakan sumber keunggulan komparatif bagi Indonesia.

e. Berdasarkan jenis usaha, 3 (tiga) jenis usaha yang paling dominan di provinsi Jawa Barat adalah: Seni dan Budaya (38\%), Kerajinan (15\%), dan Desain (15\%). Tiga jenis usaha tersebut dimungkinkan karena merupakan sektor dengan barrier entry yang rendah sehingga membuat pengusaha lain juga dapat melakukan usaha yang serupa. Selain itu sektor tersebut tidak membutuhkan modal yang besar, bisa didasarkan pada hobi menjadikan sektor ini banyak diminati pengusaha.

f. Berdasarkan jumlah karyawan, gambaran jumlah karyawan pada industri kreatif yang ada didominasi oleh jumlah karyawan 1 s.d 5 orang $(55 \%)$. Berdasarkan pendapatan pertahun, sebagian besar bermodal 0-10 juta (31\%). Modal usaha yang digunakan dalam industri kreatif adalah: < 10 juta (28\%) dan 20-30 juta (41\%). Dari data tersebut berarti bahwa usaha kreatif didominasi oleh usaha mikro.

g. Berdasarkan pangsa pasar, industri kreatif di Jawa Barat sebagian besar dinikmati oleh pasar lokal (31\%). Untuk lebih mengembangkan ekonomi kreatif Jawa Barat perlu diupayakan untuk membidik pasar di luar Jawa Barat.

h. Berdasarkan supply bahan, bahan sebagian didapat dari lokal (38\%) dan lingkup Provinsi Jawa Barat (40\%). Kemudahan dalam bahan baku ini memungkinkan potensi ekonomi kreatif untuk lebih berkembang lagi dikarenakan efisien dari biaya produksi.

i. Berdasarkan ber badan hukum/tidak, sebagain besar usaha kreatif tidak berbadan hukum (71\%) dan yang sudah berbadan hukum berjumlah 29\%. Berdasarkan merk/ produk, sebagain besar merk/ produk industri kreatif tidak terdaftar $(81 \%)$ dan yang terdaftar hanya 19\%. Hal ini perlu segera ditangani karena kondisi berbadan hukum/ tidak dan daftar merk 
sangat berpengaruh pada keberlangsungan usaha ekonomi kreatif.

j. Berdasarkan asal sumber modal, modal yang digunakan dalam usaha industri kreatif sebagian besar adalah dari tabungan pribadi/ pinjaman keluarga (44\%). Kondisi ini selaras dengan data bahwa usaha ekonomi kreatif sebagian besar masih dalam skala kecil. Selain itu kondisi usaha kreatif yang sebagian belum berbadan hukum mempengaruhi cara pengusaha untuk mendapatkan sumber modal. Di sisi lain perbankan masih perlu didorong untuk lebih berperan dalam pembiayaan usaha kreatif.

k. Berdasarkan dukungan yang dibutuhkan oleh pelaku industri kreatif, hal-hal yang dibutuhkan adalah: pemasaran (30\%), keuangan (23\%), karyawan (19\%), HKI (14\%), prasarana umum $(13 \%)$, lain-lain (1\%). Hal ini harus dijadikan fokus dalam memberikan bantuan kepada pelaku usaha kreatif.

Berbagai permasalahan yang dihadapi Jawa

Barat dalam mengembangkan ekonomi kreatif diantaranya adalah:

a. Masih sulit sekali memisahkan antara sub sektor industri kreatif dengan sekor lainnya yang selama ini digunakan. Definisi kreatif sendiri masih sulit dipahami oleh seluruh stakeholder. Hal ini berimbas pada penganggaran yang belum khusus bernama kegiatan ekonomi kreatif. Jika dikhususkan tentang industri kreatif maka dimungkinkan bisa double counting dgan sektor lain karena industri kreatif bisa masuk di sektor manapun.

b. Belum maksimalnya kebijakan yang mendukung iklim kreatif (perijinan, investasi, insentif, dan perlindungan hak cipta)

c. Kondisi pengembangan industri kreatif sangat butuh komitmen pimpinan daerah. Tataran kebijakan di provinsi sudah dilaksanakan, tapi di Kabupaten/kota belum. Belum dirasakan adanya sinkronisasi program kreatif dari provinsi dengan Kabupaten/Kota

d. Kondisi infrastruktur di masing-masing Kabupaten/Kota masih belum merata dan perlu ditingkatkan.

e. Masalah permodalan di para pelaku usaha

f. Tingkat kebutuhan pendidikan dan pelatihan yang tepat sasaran bagi ekonomi kreatif Jawa Barat masih perlu ditingkatkan

Daya dukung riset dan pengembangan terhadap ekonomi kreatif Jawa Barat masih kurang, salah satu dampaknya belum ada kajian rantai nilai yang utuh mulai kegiatan kreasi, produksi, dan distribusi

\section{SIMPULAN}

Simpulan yang dapat disampaikan dari penelitian ini antara lain: pertama, pemerintah Provinsi Jawa Barat sangat mendukung pengembangan ekonomi kreatif di wilayahnya.
Pemda Provinsi Jabar telah sangat siap melaksanakan amanat Inpres No 6 tahun 2009 tentang Pengembangan Ekonomi Kreatif. Hal ini dibuktikan dengan adanya kebijakan-kebijakan yang telah dikeluarkan oleh Pemda terkait hal tersebut,seperti Cetak Biru Rencana Pengembangan Industri Kreatif Jawa Barat, Keputusan Gubernur Jawa Barat No. 500/Kep.146-Bapp/2012 tentang Komite Pengembangan Ekonomi Kreatif Jawa Barat, dan adanya Rencana Aksi Pengembangan Ekonomi Kreatif di Jawa Barat. Selain dari sisi kebijakan, kondisi SDM dan kesiapan pendanaan juga sangat mendukung pengembangan ekonomi kreatif di Jawa Barat. Peran serta pemerintah dalam pengembangan ekonomi kreatif tidak bisa disamakan dengan campur tangan pemerintah terhadap kebijakan lainnya. Peran pemerintah bukan dalam pengembangan kreatifitas tapi menciptakan kondisi bagaimana usaha kreatif dapat terus berjalan dan semakin berkembang.

Kedua, kondisi ekonomi kreatif di Jawa Barat telah berkembang turun temurun dan didukung oleh kondisi keunggulan/ potensi kreatif yang berbeda dari provinsi lain. Berdasarkan potensinya yang besar, selain mempunyai 14 subsektor basis industri kreatif yang dicanangkan oleh Kementerian Perdagangan, Jawa Barat menetapkan 1(satu) subsektor industri kreatif tambahan yaitu KULINER . Namun demikian, Provinsi Jawa Barat menentukan 3 (tiga) subsektor unggulan yang akan dikembangkan yaitu kuliner, fesyen, dan kerajinan karena ketiga unggulan ini memberikan sumbangan pada PDRB dan penyerapan tenaga kerja. Dari data yang ada, usaha kreatif didominasi oleh usaha mikro. Pangsa pasar industri kreatif di Jawa Barat sebagian besar dinikmati oleh pasar lokal. Bahan baku sebagian didapat dari lingkup Provinsi Jawa Barat. Sebagain besar usaha kreatif tidak berbadan hukum. Sebagian besar merk/ produk industri kreatif tidak terdaftar. Berdasarkan asal sumber modal, modal yang digunakan dalam usaha industri kreatif sebagian besar adalah dari tabungan pribadi/ pinjaman keluarga. Berdasarkan dukungan yang dibutuhkan oleh pelaku industri kreatif, yang dibutuhkan adalah pemasaran, keuangan, karyawan, HAKI, prasarana umum, dan lain-lain. Hal ini harus dijadikan fokus dalam memberikan bantuan kepada pelaku usaha kreatif.

Ketiga, masalah yg dirasa menghambat dalam pengembangan ekonomi kreatif di Jawa Barat dinventarisasi sebagai berikut:

a. Masih sulit sekali memisahkan antara sub sektor industri kreatif dengan sektor lainnya yang selama ini digunakan. Definisi kreatif sendiri masih sulit dipahami oleh seluruh stakeholder. Hal ini berimbas pada perhitungan spesifik terhadap perkembangan ekonomi kreatif dan penganggaran yang belum khusus bernama kegiatan ekonomi kreatif. 
b. Belum maksimalnya kebijakan yang mendukung iklim kreatif (perijinan, investasi, insentif, dan perlindungan hak cipta)

c. Kondisi pengembangan industri kreatif sangat butuh komitmen pimpinan daerah. Tataran kebijakan di provinsi sudah dilaksanakan, tapi di Kabupaten/kota belum. Belum dirasakan adanya sinkronisasi program kreatif dari provinsi dengan Kabupaten/Kota

d. Kondisi infrastruktur di masing-masing Kabupaten/Kota masih belum merata dan perlu ditingkatkan.

e. Masalah permodalan di para pelaku usaha

f. Tingkat kebutuhan pendidikan dan pelatihan yang tepat sasaran bagi ekonomi kreatif Jawa Barat masih perlu ditingkatkan

g. Daya dukung riset dan pengembangan terhadap ekonomi kreatif Jawa Barat masih kurang, salah satu dampaknya belum ada kajian rantai nilai yang utuh mulai kegiatan kreasi, produksi, dan distribusi

\section{Saran}

Berdasarkan simpulan yang disampaikan sebelumnya, diajukan saran sebagai berikut: pertama, perlu penekanan dari Kemendagri terhadap pemerintah daerah khususnya Kabupaten/Kota agar lebih berkomitmen terhadap pengembangan ekonomi kreatif. Bentuk penekanan dapat berupa kebijakan/ aturan yang langsung berkaitan dengan ekonomi kreatif di Kabupaten/ Kota. Hal ini dimaksudkan agar pemerintah Kabupaten/Kota dapat lebih berperan dalam mengatasi berbagai permasalahan teknis terkait pengembangan ekonomi kreatif di wilayahnya. khususnya terkait fasilitasi dalam hal pemasaran, badan hukum, merk dagang, dan pembiayaan.

Kedua, kebijakan/ pembinaan dalam pengembangan usaha kreatif bisa dalam bentuk:

a. Pemasaran/ kerjasama dalam melakukan pameran

b. Mempermudah akses pelaku usaha kreatif kepada perbankan untuk memberikan bantuan keuangan bagi pelaku usaha

c. Memberi kemudahan dalam perlindungan HAKI bagi setiap hasil kreatif ( Indonesia harus mampu membangun landasan HKI yang bersifat ketimuran yang kuat, karena HKI di dunia timur banyak berupa nilai-nilai kearifan budaya lokal yang bersifat kebersamaan (togetherness) dan berbagi (Sharing).

d. Mengingat bahan baku yang digunakan diperoleh baik dari luar kabupaten/ kota di lingkungan Jawa Barat, perlu adanya peningkatan kerjasama antara Provinsi dan Kabupaten/Kota, antar Kabupaten/ Kota,dengan provinsi lainnya untuk

e. menjaga dan meningkatkan keberlanjutan bahan baku yang diperlukan

\section{DAFTAR PUSTAKA}

Bappeda, (2011), Strategi Perencanaan Pengembangan Ekonomi Kreatif Provinsi Jawa Barat, Bandung

Departemen Pendidikan dan Kebudayaan dan Balai Pustaka (1996), Kamus Umum Besar Bahasa Indonesia, Jakarta: Balai Pustaka, Ed. Kedua, Cet. Ketujuh.

Dinas Perindustrian dan Perdagangan, (2011), Pengembangan Ekonomi Kreatif, Peluang Usaha Inovatif, Bandung

Dinas Perindustrian dan Perdagangan, Peta Panduan Pengembangan Industri Unggulan Provinsi Jawa Barat, Bandung

Florida, Richard (2002), The Rise Of The Creative Class, New York, dalam Kemendag (2008).

Irfan, Islamy (1992), Prinsip-Prinsip Perumusan Kebijaksanaan Negara, Jakarta: Bumi Aksara, Cet. Keenam.

Kementerian Perdagangan R.I, (2008), Pengembangan Ekonomi Kreatif Indonesia 2025.

-----------, (2010), Laporan Pengembangan Ekonomi Kreatif.

Lembaran Administrasi Negara (LAN RI), (1991), Sistem Administrasi Negara, Jakarta: Yayasan Penerbit Administrasi, terbitan kelima.

Pink L Daniel, (2005), The Whole New Mind, dalam Kemendag 2008.

Singarimbun, Masri dan Sofian Effendi (1989), Metode Penelitian Survey, Jakarta: LP3ES.

Sugiyono, (2008), Metode Penelitian Kuantitatif, Kualitatif RD, Bandung: Alfabitan, Cet. Kelima.

Simatupang, Tobing M, (2007), Cetak Biru Rencana Pengembangan Industri Kreatif Jawa Barat, Presentasi Seminar Pengembangan Industri Kreatif Jawa Barat, Bandung 